\title{
PELATIHAN PEMBUATAN KOMPOS BLOK DENGAN MEMANFAATKAN SAMPAH ORGANIK RUMAH TANGGA UNTUK DIGUNAKAN SEBAGAI BAHAN MEDIA TANAM
}

\author{
Dhian Rosalina ${ }^{1)}$, Yenni Marnita ${ }^{2}$, Nasrul Kahfi Lubis ${ }^{3)}$, Fiddini Alham ${ }^{4)}$ \\ 1)Program Studi Manajemen, Fakultas Ekonomi, Universitas Samudra, Langsa, Aceh, Indonesia \\ 2)Program Studi Agroteknologi, Fakultas Pertanian, Universitas Samudra, Langsa, Aceh, Indonesia \\ 3)Program Studi Akuntansi, Fakultas Ekonomi, Universitas Samudra, Langsa, Aceh, Indonesia \\ 4)Program Studi Agribisnis, Fakultas Pertanian, Universitas Samudra, Langsa, Aceh, Indonesia \\ Corresponding author : Dhian Rosalina \\ E-mail : dhian.rosalina@unsam.ac.id
}

Diterima 06 September 2021, Direvisi 17 September 2021, Disetujui 17 September 2021

\begin{abstract}
ABSTRAK
Kegiatan pengabdian ini merupakan pelatihan bagaimana memanfaatkan sampah organik rumah tangga menjadi kompos blok sehingga bisa digunakan sebagai bahan media tanam di tengah tren berkebun yang sedang digemari masyarakat. Tujuan dari kegiatan ini adalah membina mitra untuk dapat mengolah sampah organik rumah tangga yang selama ini hanya dibuang begitu saja menjadi produk yang bermanfaat seperti kompos. Kompos blok merupakan produk inovasi yang memanfaatkan limbah organik menjadi olahan kompos yang dalam proses pengerjaanya dicetak menjadi blok menggunakan alat cetak sederhana dari kayu, sehingga dapat digunakan sebagai media tanam dalam budidaya pertanian berbasis urban farming. Kegiatan pengabdian dilaksanakan di Gampong Baroh Langsa Lama, kota Langsa Aceh, dengan 30 orang buruh harian lepas sebagai mitra. Metode yang digunakan adalah sosialisasi, pelatihan dan praktik, serta evaluasi. Hasil dari kegiatan ini adalah 50 persen mitra bersedia melakukan praktik pembuatan kompos blok di tempat tinggal masing masing dan bersedia dievaluasi oleh tim pengabdian secara berkala.
\end{abstract}

Kata kunci: Sampah organic; kompos blok; urban farming.

\begin{abstract}
This community service activity is a training to utilize household organic waste into compost blocks so that it can be used as planting media material. So, it can support gardening trends that are popular with the community. The purpose of this activity is to train partners to be able to process household organic waste into useful products such as compost. Block compost is an innovative product that utilizes organic waste into compost which in the process is formed into blocks using a simple wooden press so that it can be used as a planting medium in urban farming-based agricultural cultivation. Community service activities were carried out in Gampong Baroh Langsa Lama, Langsa Aceh city, with 30 day laborer as partners. The methods used are socialization, training and practice, and evaluation. The result of this activity is that 50 percent of partners are willing to practice making compost blocks and are willing to be evaluated by the community service team periodically
\end{abstract}

Keywords: Organic waste; block compost; urban farming.

\section{PENDAHULUAN}

Pandemi covid 19 yang melanda dunia dan khususnya di Indonesia masih terus berlangsung sampai dengan saat ini, pandemic yang belum benar benar terkendali ini mengakibatkan dampak yang luar biasa bagi masyarakat. Dilansir dari tirto.id bahwa Per 29 Maret 2021 dari 46.933 spesimen yang diperiksa, hasilnya 5.008 orang positif terinfeksi, jumlah penderita sembuh sebanyak 5.418 pasien, dan 132 orang meninggal. Penurunan pertumbuhan ekonomi merupakan dampak yang nyata dari imbas panjangnya pandemic saat ini. Hal ini disebabkan karena adanya pembatasan sosial secara besar besaran di yang memaksa pola hidup dan aktivitas masyarakat sebisa mungkin dilaksanakan di rumah. Pembatasan Sosial Berskala Besar yang kemudian dikenal sebagai Pemberlakuan Pembatasan Kegiatan Masyarakat (PPKM) berdampak pada menurunnya aktivitas ekonomi, sehingga banyak kegiatan bisnis yang tidak beroperasi dengan maksimal, sehingga secacar langsung berdampak kepada penurunan daya beli masyarakat (Mustofa \& Suhartatik, 2020). Tidak hanya itu saja, dalam 
bidang pendidikan pun, pemberlakuan belajar secara daring diterapkan pada daerah dengan zona tertentu yang terindikasi tingkat penyebaran tinggi, sehingga praktis kehidupan masyarakat banyak berkutat di lingkungan rumah.

Gampong Baroh Langsa Lama merupakan salah satu gampong yang ada di Kecamatan langsa Lama, dengan jumlah penduduk mencapai 33.231 jiwa (BPS, 2021). Gampong Baroh Langsa Lama memiliki kepadatan penduduk, dilansir dari data BPS Kota langsa, tingkat kepadatan penduduk gampong mencapai 811 orang per kilometer persegi. Topografi gampong Kota Langsa juga mempunyai memiliki karakteri dataran rendah dan bergelombang, dialiri oleh sungai sungai. Dengan luas $45 \mathrm{~km} 2$ dan jarak ke ibukota proovinsi mencapai 443 kilometer.

Pemenuhan kebutuhan pokok masyarakat tentu tindak akan berhenti ditengah pandemic.. Ketahanan pangan merupakan aspek penting, dalam memenuhi gizi seimbang untuk menghadapi dan meminimalkan resiko berat dari paparan wabah pandemik (Rizqi Zati, Murdhiani, \& Rosalina, 2020). Ketahanan pangan merupakan aspek penting dalam mendukung pola hidup sehat, ketahanan pangan dapat membantu imunitas masyarakat menghadapi wabah yang belum berakhir sembari menunggu herd immunity yang terbentuk dari program vaksinasi yang sedang dilaksanakan pemerintah. Budaya berkebun yang saat ini menjadi tren, dapat menjadi momentum untuk membentuk ketahanan pangan.masyarakat. Seperti diketahui, setiap rumah tangga memiliki limbah organic seperti kulit buah, sisa sayuransegar, dan kotoran ternak (Pudjojono \& Suryaningrat, 2008) kegiatan pengabdian ini fokus pada pelatihan pembuatan kompos blok, kompos blok merupakan salah satu jenis olahan kompos yang dalam proses pengerjaanya dicetak menjadi blok - blok menggunakan bantuan mesin press. Kompos blok merupakan produk inovasi kompos yang dapat berfungsi menggantikan kompos biasa, (Novita, Fathurrohman, \& Pradana, 2018). Pemanfaatan limbah organik rumah tangga untuk dijadikan bahan baku pembuatan kompos blok sebagai media tanam merupakan salah satu inovasi yang dapat dikembangkan di era pandemi. Kompos blok bertujuan memanfaatkan limbah organik menjadi bernilai tinggi sehingga tidak mubadzir $\mathrm{Hal}$ ini selain digunakan sebagai media tanam namun juga bertujuan untuk memanfaatkan sisa limbah organik yang tidak terpakai agar lebih bermanfaat serta mengurangi limbah plastik dari penggunaan polybag.Kompos blok sendiri dapat digunakan sebagai media tanam dalam budidaya pertanian berbasis urban farming. Pengembangan budidaya pertanian berupa urban farming di era pandemi ini merupakan upaya yang siginikan guna memenuhi kebutuhan pangan masyarakat, mengingat bahwa tingkat kemisikinan di kota Langsa sendiri pada tahun 2020 mencapai 10,44\%, sehingga pelatihan pembuatan kompos blok di Gampong Baroh Langsa Lama diharapkan dapat memberikan edukasi secara langsung untuk mengatasi kurangnya ketersediaan pangan dan mendukung program ketahanan pangan pemerintah.

Kegiatan pengabdian ini dilaksanakan di Gampong Baroh Langsa Lama, dengan buruh harian lepas yang merasakan langsung dampak pandemi sebagai mitra. Tujuan dari kegiatan pengabdian adalah meningkatkan kemampuan mitra dalam praktek budidaya pertanian dengan memanfaatkan limbah organik sebagai kompos blok, sehingga ditengah ketidak pastian wabah mitra tetap dapat memenuhi kebutuhan gizi keluarga dari pekarangan rumah.

Permasalahan yang dihadapi mitra saat ini adalah sebagai berikut :

a. Minimnya pengetahuan masyarakat, khususnya mitra yang merupakan ibu rumah tangga di gampong Baroh Langsa Lama dalam berinovasi mengelola limbah organik di lingkungan rumah menjadi pupuk kompos. Hal ini terlihat dari kebiasaan membuang atau membakar limbah organik begitu saja tanpa ada pengolahan atau pemanfaatan sebagai pupuk.

b. Kurangnya pelatihan inovasi dalam memanfaatkan limbah organik, seperti pembuatan kompos blok. Pelatihan yang berhubungan kepada ketahanan pangan lebih banyak pada bidang pemanfaatan media tanam, dan masih sangat sedikit tim yang concern pada inovasi pupuk.

Tujuan dari kegiatan ini adalah membina mitra untuk dapat mengolah sampah organik rumah tangga yang selama ini hanya dibuang begitu saja menjadi produk yang bermanfaat seperti kompos. Kompos blok merupakan produk inovasi yang memanfaatkan limbah organik menjadi olahan kompos yang dalam proses pengerjaanya dicetak menjadi blok menggunakan alat cetak sederhana dari kayu yang berukuran $10 \times 5 \mathrm{~cm}$, sehingga dapat digunakan sebagai media tanam dalam budidaya pertanian berbasis urban farming. 


\section{METODE}

Pelaksanaan kegiatan Pengabdian Masyarakat dilakukan di Desa Baroh Langsa Lama Kecamatan Langsa Lama Kota Langsa. Peserta mitra binaan yang bekerjasama dalam kegiatan pengabdian ini adalah tiga puluh orang buruh harian lepas.

Terdapat tiga tahap pelaksanaan kegiatan pengabdian. Tahap pertama adalah tahap persiapan yang meliputi observasi masalah mitra dan koordinasi dengan perangkat desa, tahap kedua adalah tahap administrasi, yang berhubungan dengan masalah perizinan dan lokasi kegiatan, tahap ketiga adalah pelaksanaan pelatihan dan evaluasi.

Pada tahap persiapan, tim pengabdian melakukan kegiatan observasi dengan mendatangi kelompok buruh harian lepas di Desa Baroh Langsa Lama untuk mendapatkan gambaran mengenai masalah yang dihadapi mitra, materi pengabdian dan bagaimana teknik pelaksanaan kegiatan. Setelah melakukan observasi, tim melakukan kunjungan ke kantor kelurahan atau biasa disebut geuchik untuk menyampaikan maksud pelaksanaan kegiatan pengabdian.

Tahap pelaksanaan kegiatan dilaksanakan dalam tiga kali pertemuan. Pada pertemuan I akan dilaksanakan kegiatan penyuluhan pentingnya menjaga kebersihan lingkungan dengan memanfaatkan sampah organik sebagai bahan untuk pembuatan kompos. Pada pertemuan II cara membuat kompos dari sampah organik rumah tangga. Pertemuan III akan dilaksanakan kegiatan pencetakan kompos blok.

Tahap evaluasi dilakukan dengan melihat respon para buruh harian lepas baik melalui pertanyaan pretest dan post-test terkait materi pengabdian. Tahap evaluasi dilakukan dengan menggunakan kuesioner terhadap reakasi mitra dalam pemahaman materi yang disampaikan melalui media pembelajaran yang disampaikan.

\section{HASIL DAN PEMBAHASAN}

Kegiatan pengabdian masyarakat pelatihan pembuatan kompos blok dilaksanakan pada bulan Juli sampai dengan Agustus 2021. Dengan mengundang buruh harian lepas di Gampong Baroh Langsa Lama. Tahapan dalam kegiatan pengabdian adalah sebagai berikut :

\section{Tahap Sosialisasi}

Dalam sosialisasi, sebelum melakukan kegiatan tim melakukan observasi terlebih dahulu terhadap kondisi yang ada di Gampong Baroh Langsa Lama. Berdasarkan observasi yang dilakukan tim, masyarakat desa belum memanfaatkan limbah organik dengan baik. Masyarakat pada umumnya langsung membuang limbah organik rumah tangga seperti sisa sayuran ke tempat sampah. Begitu juga dengan sampah pekarangan, yang biasa dibakar begitu saja tanpa pengolahan lebih lanjut. Dengan fenomena tersebut, masyarakat memerlukan edukasi dalam memaksimalkan limbah organik di lingkungan tempat tinggalnya, dapat mendukung budaya berkebun yang saat ini sedang tren, apalagi saat ini Kota Langsa sedang berada dalam zona merah pandemi covid 19 dimana terdapat pembatasan dalam aktivitas masyarakat, dengan kondisi sosial ekonomi masyarakat Desa Baroh Langsa Lama yang banyak berprofesi sebagai buruh harian lepas, maka dampak pembatasan cukup memukul ekonomi warga.

Dari hasil pengamatan yang dilakukan oleh tim, maka kegiatan pengabdian fokus pada pemanfaatan limbah organik rumah tangga, sehingga dapat mendukung tren berkebun yang sedang melanda warga.

Kemudian setelah tim mendapatkan kesepakan kegiatan baik dari mitra dan kantor kelurahan, disepakati bahwa kegiatan dilaksanakan dan difasilitasi di ruang serba guna kantor Gampong. Tim melakukan sosialisasi kegiatan dengan mengundang mitra untuk dapat hadir pada kegiatan tersebut, undangan dan sosialisasi dilakukan dalam bentuk poster/baliho di kantor geuchik, kemudian undangan melalui whatsapp kepada mitra yang sudah didata oleh tim.

\section{Tahap Pelaksanaan}

Setelah melakukan kegiatan observasi, tim melakukan komunikasi dengan aparat Desa, yang mana di Kota Langsa biasa disebut geuchik. Dari hasil koordinasi disepakati bahwa kegiatan dilaksanakan dan difasilitasi di ruang serba guna kantor Gampong. Tahap pelaksanaan terdiri dari kegiatan - kegiatan sebagai berikut :

\section{a. Penyuluhan Sampah Organik \\ Kegiatan penyuluhan sampah organik} merupakan awal dari kegiatan tim pengabdian, dimana dalam kegiatan ini tim memberikan edukasi mengenai pengenalan limbah organik yang dapat digunakan masyarakat untuk membuat kompos blok. Kegiatan ini dilakukan pada tanggal 2 Agustus 2021 di ruang serbaguna geuchik dengan tetap menjalan protocol kesehatan pandemic covid 19. 


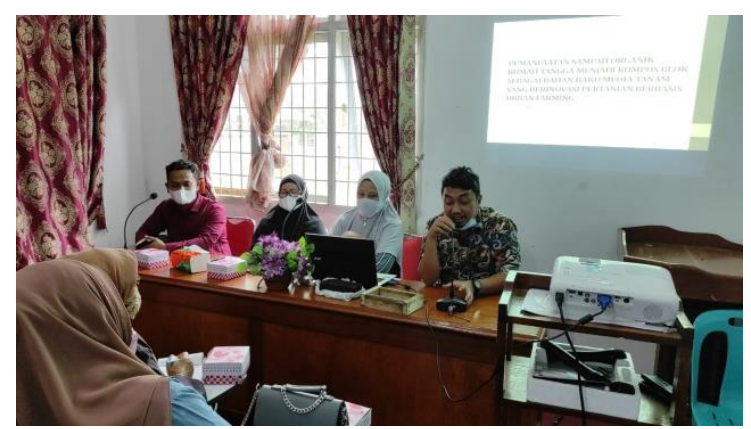

Gambar 1. Kegiatan Penyuluhan Limbah Organik

Dalam gambar 1 di atas, tim sedang melaksanakan kegiatan penyuluhan, pada saat pelaksanaan kegiatan tersebut tim memberikan video simulasi proses pembuatan kompos blok. Tim juga memberikan wawasan tambahan mengenai prospek peluang ekonomi apabila mitra mampu memproduksi pupuk kompos blok dengan baik, sehingga dapat menambah penghasilan mitra.

b. Pelatihan membuat kompos dari sampah organik rumah tangga

Praktik pelatihan dilaksanakan pada tanggal 3 Agustus 2021, di salah satu kediaman mitra. Pada kegiatan ini, tim mempraktikkan pembuatan kompos blok dengan tahapan sebagai berikut :

1. Persiapan sampah organik seperti sisa sayuran, sampah tumbuhan di pekarangan (rontokan daun dari pohon di pekarangan), dan kulit buah

2. Sampah organik tersebut dimasukkan ke dalam media yang sudah disiapkan sebelumnya, seperti tabung bekas cat atau pot, sebagaimana yang dapat dilihat pada gambar 2 berikut ini :

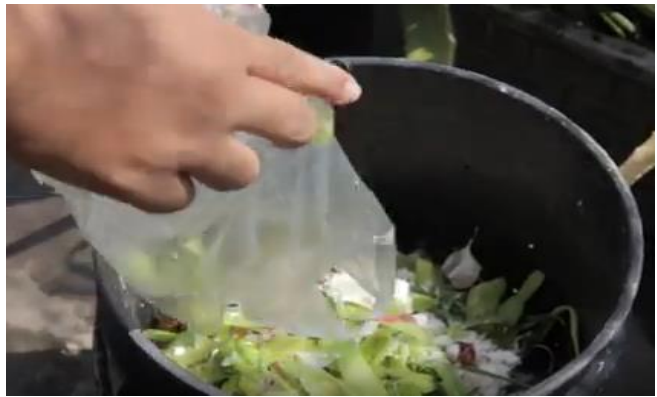

Gambar 2. Pengumpulan sampah organik

3. Sampah organik tersebut diberi larutan dekomposer EM 4 yang berfungsi untuk mempercepat proses dekomposisi atau penguraian bahan organik.
4. Sampah organik tersebut juga ditambahkan dengan sedikit tanah pupuk atau tanah hitam, kemudian diaduk sampai tercampur seluruh bahan yang ada dalam wadah.

5. Tutup media pengomposan agar terjadi fermentasi sempurna.

Setelah kegiatan membuat bahan kompos blok selesai, tim mendiskusikan waktu pertemuan selanjutnya untuk mencetak kompos sembari menunggu proses fermentasi bahan pupuk.

c. Pelatihan mencetak pupuk kompos blok

Pelatihan selanjutnya adalah membuat mencetak kompos, tahapan tahapan yang dilakukan adalah sebagai berikut :

1. Fermentasi kompos memakan waktu kurang lebih 2 minggu

2. Kompos yang telah difermentasi dicampurkan dengan perekat berupa larutan kanji yang telah dipanaskan hingga mengental

3. Masukkan kompos yang telah dalam cetakan yang disiapkan (cetakan bisa dibentuk dari kayu dengan ukuran $10 \mathrm{x}$ $5 \mathrm{~cm}$.

4. Kompos yang telah dicetak selanjutnya dijemur dibawah sinar matahari hingga kering.

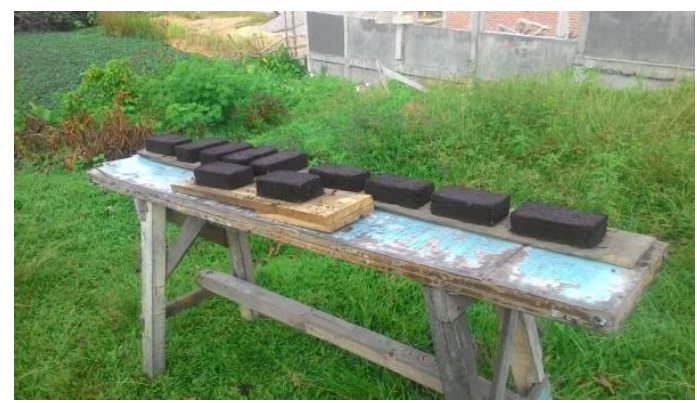

Gambar 3. Proses Pembuatan dan Penjemuran Kompos Blok

5. Kompos siap untuk digunakan oleh mitra

Mitra cukup antusias mengikuti kegiatan, hal ini terlihat seluruh peserta mengikuti setiap tahapan kegiatan sampai dengan selesai. Kegiatan ini diakhiri dengan sesi tanya jawab. Banyak pertanyaan yang diajukan oleh mitra seperti komposisi tanah pupuk atau tanah hitam, dekomposer EM 4, jenis tanah yang digunakan dalam proses pembuatan pupuk kompos, cara meletakkan benih tanaman, sampai dengan prospek ekonomi dari bisnis kompos blok. Tim merespon pertanyaan mitra baik dengan reka ulang pembuatan pupuk dan menunjukkan 
simulasi video pembuatan sampai dengan mitra puas dengan jawaban yang diberikan oleh tim.

\section{Tahap Evaluasi}

Tahap evaluasi adalah dengan melakukan post test mengenai teknis pembuatan kompos blok, dan $70 \%$ dari keseluruhan mitra mampu memguraikan tahapan pembuatan pupuk kompos blok.

Setelah kegiatan post test usai, tim meminta mitra untuk melakukan praktik membuat kompos blok dirumah masing masing. Tim pengabdian melakukan monitoring ke rumah mitra secara berkala untuk mengevaluasi keberhasilan program pengabdian.

\section{SIMPULAN DAN SARAN Simpulan}

Kesimpulan dari kegiatan ini adalah Pertama, mitra mengikuti seluruh kegiatan dengan baik sampai selesai. Mitra mendapatkan wawasan baru dalam mengolah limbah organik rumah tangga seperti sisa sayuran, kulit buah, dan sampah daun pekarangan menjadi produk yang memiliki manfaat tinggi. Kedua, dengan adanya tren kebiasaan berkebun, memberikan motivasi bagi mitra untuk meningkatkan kualitas hasil kebun dengan memanfaatkan limbah organik menjadi pupuk kompos. Ketiga,

dengan kondisi pandemik covid 19 yang masih berlangsung, mitra memiliki peluang menambah penghasilan dengan membuat kompos blok yang menggunakan bahan sampah organik rumah tangga. Keempat, efektivitas hasil dari kegiatan pengabdian adalah kesungguhan mitra melakukan praktik membuat kompos blok di rumah dan bersedia untuk di evaluasi oleh tim pengabdian.

\section{Saran}

Saran dalam kegiatan ini adalah Pertama, perlu adanya pelatihan lebih lanjut dalam memaksimalkan pemanfaatan sumber daya yang dimiliki mitra. Mengingat kondisi mitra adalah buruh harian lepas, dimana pelatihan tersebut dapat memanfaatkan benda benda disekitar tempat tinggal yang murah dan mudah didapatkan. Kedua, Perlu adanya motivasi bagi mitra bahwa dalam setiap kegiatan pengabdian yang dilakukan dapat memberikan penghasilan tambahan apabila mitra menekuni dan mampu memperbaiki kualitas produk. Dengan demikian kegiatan pengabdian dapat memberikan manfaat ekonomi secara jangka panjang bagi masyarakat

\section{UCAPAN TERIMAKASIH}

Tim pengabdian masyarakat mengucapkan terima kasih kepada Geuchik Gampong Baroh Langsa Lama yang telah memberikan izin dan memfasilitasi lokasi kegiatan kepada tim. Ucapan terimakasih juga tim sampaikan kepada masyarakat buruh harian lepas di Gampong yang bersedia meluangkan waktu mengikuti dan mempraktikkan pembuatan kompos blok sampai siap digunakan. Tidak lupa pula tim mengucapkan terima kasih kepada Universitas Samudra yang bersedia mendanai kegiatan pengabdian kepada masyarakat yang dilakukan oleh tim.

\section{DAFTAR RUJUKAN}

BPS. (2021). Kota Langsa Dalam Angka 2021 (B. K. Langsa, ed.). Langsa: BPS Kota Langsa.

Mustofa, A., \& Suhartatik, N. (2020). MENINGKATKAN IMUNITAS TUBUH DALAM MENGHADAPI PANDEMI. Jurnal Pengabdian Masyarakat Berkemajuan, 4(November), 324-332.

Novita, E., Fathurrohman, A., \& Pradana, H. A. (2018). PEMANFAATAN KOMPOS BLOK LIMBAH KULIT KOPI SEBAGAI MEDIA TANAM (the Utilization of Coffee Pulp and Coffee Husk Compost Block as Growing Media) Elida Novita 1 , Anis Fathurrohman 1, Hendra Andiananta Pradana 2. Jurnal Agrotek, 2(2), 61-72.

Pudjojono, M., \& Suryaningrat, I. B. (2008). Pemanfaatan Limbah Pengolahan Kopi Sebagai Pupuk Organik Kompos Blok. 111.

Rizqi Zati, M., Murdhiani, M., \& Rosalina, D. (2020). Pelatihan Budidaya Metode Vertical Garden Dalam Menghadapi Masa Pandemi Covid 19. SELAPARANG Jurnal Pengabdian Masyarakat Berkemajuan, 4(1), 306. https://doi.org/10.31764/jpmb.v4i1.3006 